\title{
Molecular studies of Callithrix pygmaea (Primates, Platyrrhini) based on transferrin intronic and ND1 regions: implications for taxonomy and conservation
}

\author{
Claudia Helena Tagliaro ${ }^{I}$, Maria Paula Cruz Schneider ${ }^{2}$, Horacio Schneider ${ }^{\text {, }}$ \\ Iracilda Sampaio ${ }^{1}$ and Michael Stanhope ${ }^{3}$
}

\begin{abstract}
Traditional classifications of Platyrrhini monkeys, based mainly on morphological features, are being contested by recent molecular data. The subfamily Callitrichinae (Platyrrhini, Primates) consists of a diverse group of species, many of them considered endangered. Our analysis of two DNA regions, a mtDNA gene (ND1) and a nuclear gene (intronic regions of the transferrin gene), suggests that Callithrix pygmaea may have sufficient variability to justify the existence of subspecies or even separate species. Phylogenetic dendrograms based on the ND1 region show that this species is more closely related to Amazonian than to Atlantic forest marmosets. These results reopen the discussion about diversity and conservation programs based exclusively on traditional classifications.
\end{abstract}

\section{INTRODUCTION}

According to Schneider et al. (1996) the New World monkeys can be classified into two families: the Atelidae and the Cebidae. The latter is divided into three subfamilies: Cebinae (Cebus and Saimiri), Aotinae (Aotus) and Callitrichinae (Saguinus, Leontopithecus, Callimico and Callithrix). Some authors grouped the Callimico genus within the family Callitrichidae but allocated it to a distinct subfamily, the Callimiconinae (Napier and Napier, 1967; Ford, 1986; Kay, 1994). Dollman (1933) and Hershkovitz (1977) classified Callimico in its own family, the Callimiconidae. Thomas (1913); Simpson (1945); Stirton (1951), Cabrera (1958), and Simons (1972) included Callimico in the Cebidae family. There is a consensus that Callithrix, Leontopithecus and Saguinus all belong to the same clade but the evolutionary relationships between these genera are still controversial (Rosenberger, 1981; Ford, 1986; Schneider et al., 1996; Pastorini et al., 1998). The genus Callithrix has a wide distribution and can be divided into three distinct groups of species: the argentata group, represented by marmosets from the Amazonian forest and part of the cerrado (a type of Brazilian savanna); the jacchus group, comprising marmosets from the Atlantic forest, the cerrado and the caatinga (a dry region of stunted vegetation and brushwood) (Hershkovitz, 1977), and the pygmaea group made up of pygmy marmosets (C. pygmaea) from the Amazonian forest (Barroso et $a l .$, 1997). The pygmy marmoset was first classified as Cebuella Gray, 1866, a genus distinct from the already described Callithrix Erxleben, 1777. However, recent molecular data indicate that the pygmy marmoset should be classified as C. pygmaea (Schneider et al., 1996; Barroso et al.,
1997; Porter et al., 1997). Previously, Rosenberger (1981, 1984) had drawn attention to morphological similarities between pygmy marmosets and species of Callithrix that could justify their classification within the same genus.

Considering the system adopted by the World Conservation Union (WCU) (see Rylands et al., 1995, 1997), several species and/or subspecies of Callitrichinae are classified as critically endangered or endangered as a consequence of habitat destruction and illegal capture or hunting. According to Rylands et al. $(1995,1997)$ the following callitrichines may be classified as critically endangered: Leontopithecus rosalia, L. chrysopygus, and L. caissara whereas those on the endangered list are L. chrysomelas, C. flaviceps, C. aurita, Saguinus bicolor bicolor, and S. oedipus. Although $C$. pygmaea is affected by illegal international trade, particularly in the area of Iquitos in Peru, it is classified in the WCU's Lower Risk category (Rylands et al., 1995). Callithrix pygmaea is a small monkey and thus is not hunted for food by humans. Furthermore, it has a wide geographical distribution and is capable of existing in isolated forest patches near human settlements (see Hershkovitz, 1977; Rylands et al., 1993).

The purpose of the present study was to provide a molecular view of the relationships among the callitrichines with particular emphasis on C. pygmaea and to highlight the importance of the use of molecular studies in designing conservation programs.

\section{MATERIAL AND METHODS}

The scientific names, sample code and geographical origins of monkeys, as well as the fragments of DNA se-

${ }^{1}$ Laboratório de Genética e Biologia Molecular, Campus de Bragança, UFPA, Bragança, PA, Brasil. Send correspondence to C.H.T.E-mail:tagliaro@ufpa.br

${ }^{2}$ Laboratório de Polimorfismo de DNA, Departamento de Genética, Centro de Ciências Biológicas, UFPA, Belém, PA, Brasil.

${ }^{3}$ School of Biology and Biochemistry, Queen's University of Belfast, Belfast, Northern Ireland. 
quenced, appear in Table I. Monkeys were anesthetized with Ketalar $(10 \mathrm{mg} / \mathrm{kg}$ body weight) and blood samples collected from femoral veins. Blood samples were centrifuged and DNA extracted from the isolated leukocytes according to the protocol of Sambrook et al. (1989).

DNA sequences of the transferrin (exon 4 to exon 6) and ND1 regions were determined by direct sequencing of PCR-amplified fragments. For the ND1 fragment, a second PCR (internal) was performed on the fragment resulting from the first PCR in order to eliminate false priming products that occasionally arise in the original genomic DNA PCR. Primers for the amplification of these regions are described in Table II. The DNA sequences were determined using dye terminator cycle sequencing reactions that were subsequently loaded onto an automatic sequencer (Applied Biosystems model 373A) according to the manufacturer's protocols. Additional sequencing primers were designed as necessary.

Initial sequence alignments were performed using the Eyeball sequence editor (Cabot and Beckenback, 1989). Data were analyzed by the neighbor-joining (NJ) method using the MEGA program (Kumar et al., 1993) whereas maximum-parsimony (MP) and maximum-likelihood (ML) analyses were performed with PAUP 4.0 beta version (Swofford, 1998) using a branch and bound algorithm search (Hendy and Penny, 1982). The robustness of the phyloge- netic hypothesis obtained by MP was tested by bootstrapping (Felsenstein, 1985) and the criterion adopted to evaluate it was that suggested by Hillis and Bull (1993) who consider bootstrap values equal or superior to $70 \%$ to be statistically significant. All bootstrap analyses of DNA sequence data involved at least 2000 replications and all gaps were considered as single events. NJ analyses of the DNA sequence data were performed using the method of Jukes and Cantor (1969) for the transferrin fragment and that of Tamura and Nei (1993) for the mtDNA region (ND1). The reliability of the topologies of the NJ tree branches were tested by the standard error test (SET), using the method of Jukes and Cantor (1969) for transferrin, the Kimura twoparameter distance values for the mtDNA region (Kimura, 1980), and the MEGA program (Kumar et al., 1993).

The estimated time since divergence was calculated by means of the branch lengths of the NJ trees and the method proposed by Sarich and Wilson (1973), using the estimated time of 13 million years ago (Mya) for the emergence of the tribe Callitrichini (Goodman et al., 1998).

\section{RESULTS}

The transferrin sequences determined for callitrichine representatives are $1662 \mathrm{bp}$ in length but only the intronic regions, corresponding to $1472 \mathrm{bp}$, were used in the phylo-

Table I - The origin and identification of various New World monkeys for which DNA sequences were determined.

\begin{tabular}{|c|c|c|c|}
\hline Identification code & Taxonomic identification & DNA region sequenced & Origin \\
\hline CAR-021 & Callithrix argentata & ND1 & Rio Anauera, Cametá, PA, Brazil \\
\hline CGE-083 & Callithrix geoffroyi & ND1 & Criadouro Barbuse Leal, Brasília, DF, Brazil* \\
\hline CJA-033 & Callithrix jacchus & $\begin{array}{l}\text { ND1 } \\
\text { TF }\end{array}$ & Extremós, RN, Brazil \\
\hline CKU-093 & Callithrix kuhli & ND1 & Floresta Azul, BA, Brazil \\
\hline CKU-094 & Callithrix kuhli & ND1 & Ilhéus, BA, Brazil \\
\hline CKU-095 & Callithrix kuhli & ND1 & Una, BA, Brazil \\
\hline CPE-089 & Callithrix penicillata & ND1 & Biotério da Universidade de Brasília, Brasília, DF, Brazil* \\
\hline CPE-090 & Callithrix penicillata & ND1 & Biotério da Universidade de Brasília, Brasília, DF, Brazil* \\
\hline CPE-091 & Callithrix penicillata & ND1 & Biotério da Universidade de Brasília, Brasília, DF, Brazil* \\
\hline CPE-092 & Callithrix penicillata & ND1 & Biotério da Universidade de Brasília, Brasília, DF, Brazil* \\
\hline CPE-127 & Callithrix penicillata & ND1 & Biotério da Universidade de Brasília, Brasília, DF, Brazil* \\
\hline CPE-128 & Callithrix penicillata & ND1 & Biotério da Universidade de Brasília, Brasília, DF, Brazil* \\
\hline CPE-129 & Callithrix penicillata & ND1 & Biotério da Universidade de Brasília, Brasília, DF, Brazil* \\
\hline CPE-130 & Callithrix penicillata & ND1 & Biotério da Universidade de Brasília, Brasília, DF, Brazil* \\
\hline CPY-104 & Callithrix pygmaea & $\begin{array}{l}\text { ND1 } \\
\text { TF }\end{array}$ & Centro Nacional de Primatas, Belém, PA, Brazil* \\
\hline CPY-105 & Callithrix pygmaea & $\begin{array}{l}\text { ND1 } \\
\text { TF }\end{array}$ & Centro Nacional de Primatas, Belém, PA, Brazil* \\
\hline LCH-101 & $\begin{array}{l}\text { Leontopithecus } \\
\text { chrysomelas }\end{array}$ & $\mathrm{TF}$ & Centro de Primatologia do Rio de Janeiro, RJ, Brazil* \\
\hline LCH-110 & $\begin{array}{l}\text { Leontopithecus } \\
\text { chrysomelas }\end{array}$ & ND1 & Centro de Primatologia do Rio de Janeiro, RJ, Brazil* \\
\hline CGO-111 & Callimico goeldii & $\begin{array}{l}\text { ND1 } \\
\text { TF }\end{array}$ & Municipality of Lagoínha, Rio Juruá, AC, Brazil \\
\hline SMY-045 & Saguinus mystax & ND1 & Iquitos, Peru \\
\hline CAP-048 & Cebus apella & $\begin{array}{l}\text { ND1 } \\
\text { TF }\end{array}$ & Centro Nacional de Primatas, Belém, PA, Brazil* \\
\hline
\end{tabular}

*Animals in captivity and unknown origin. 
genetic analyses. The trees obtained by NJ, ML and MP analysis all agree in their topology. The phylogenetic tree (Figure 1) shows both $C$. pygmaea individuals joining together at the same branch-point, an arrangement statistically supported by bootstrap (96\%) and SET (95\%) analysis. $C$. jacchus and $C$. pygmaea form a sister group, also considered significant by both bootstrap (100\%) and SET $(99 \%)$ analyses. The next representative to join this sister group is Callimico, supported only by bootstrap (76\%) analysis. Saguinus and Leontopithecus were the most basal genera, but it was not possible to determine which one was the first to split.

One 1321-bp fragment spanning the ND1 fragment and flanking regions was sequenced, although only sequences of $951 \mathrm{bp}$ that corresponded exclusively to the ND1 gene were considered in the analysis. The two Callithrix pygmaea (CPY-104 and CPY-105) individuals grouped together; this topology being supported by bootstrap (93\%) and SET (99\%) analysis. Representatives of the jacchus group (C. jacchus, C. penicillata, C. kuhli, C. geoffroyi) grouped together (Figure 2); an observation strongly supported by bootstrap (100\%) and SET (99\%) analyses. The existence of a Callithrix clade (containing representatives of species of the Callithrix genus, including C. pygmaea) was also supported by bootstrap (99\%) and SET (99\%) analysis. The arrangement of the dendrograms (produced by the
NJ, ML and MP methods) obtained using ND1 data are not significant and no inference can be made as to the relationships between the most basal genera of the subfamily Callitrichinae and the species of the jacchus group.

Comparison between the DNA sequences of the two pygmy marmosets sampled (CPY-104 and CPY-105) showed important differences. The intronic transferrin fragments of $1472 \mathrm{bp}$ (exon 4 to 6) had five transitions and two transversions. Sixty-two transitions and three transversions were detected among the ND1 sequences of the two pygmy marmosets sampled, which generated nine differences in the amino acid sequence of the ND1 protein. Comparison of the two sequences of the D-loop and adjacent region (GenBank numbers U89009, U89010) showed that there were 59 transitions and 36 transversions, along with three deletions of $1 \mathrm{bp}$ and one of $15 \mathrm{bp}$.

Tables III-V show the divergence matrices obtained for representatives of the subfamily Callitrichinae. Considering the ND1 fragment, both $C$. pygmaea individuals showed greater differences in their sequences and, consequently, in the divergence matrix (Table IV) than were observed in comparisons between the four species of the jacchus group. A previous study (Tagliaro et al., 1997) showed that the D-loop divergence matrix (Table V) also indicated considerable divergence between the two $C$.

Table II - Primers used for the amplification of DNA fragments of transferrin, and ND1.

\begin{tabular}{|c|c|c|}
\hline DNA fragments & Primers & Internal primers \\
\hline Transferrin & $\begin{array}{l}\text { 5' GGCAGGTCCGCTGGGTGGAACATCCCCAT3' } \\
\text { (foward) } \\
\text { 5' AAGGCCACATCCCCAGCACCATCCTTCA 3' } \\
\text { (reverse) }\end{array}$ & \\
\hline ND1 & $\begin{array}{l}\text { 5' CTACGTGATCTGAGTTCAGACCGG3' } \\
\text { (foward) } \\
\text { 5' AGGGTATAACCAACATTTTCGGGGTATG3' } \\
\text { (reverse) }\end{array}$ & $\begin{array}{l}\text { 5' CTACGTGATCTGAGTTCAGACCGG3' } \\
\text { (foward) } \\
\text { 5' CCCGATAGCTTATTTAGCTGACCTTAC3' } \\
\text { (reverse) }\end{array}$ \\
\hline
\end{tabular}

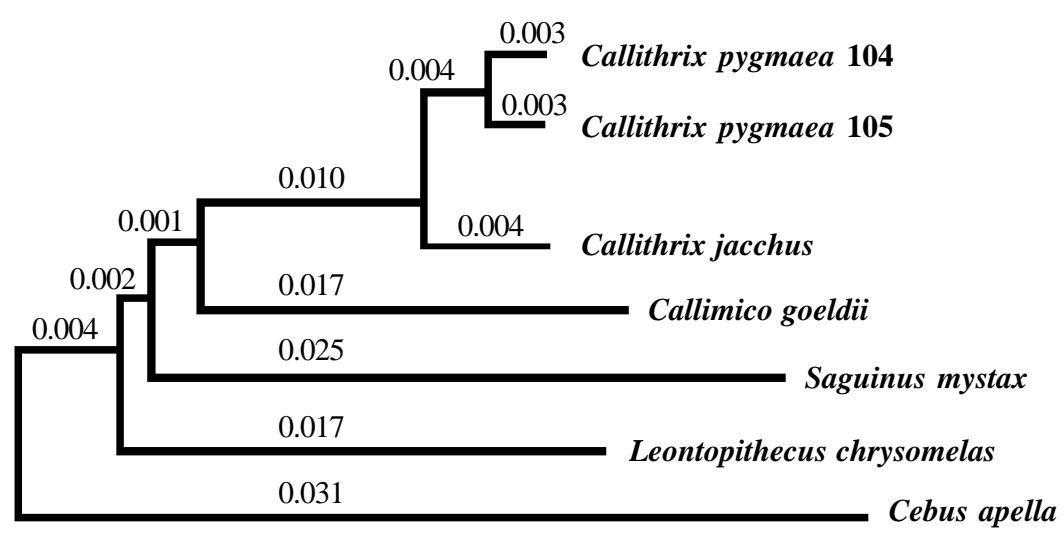

Figure 1 - Intronic transferrin sequence (exon 4 to 6) phylogenetic dendrogram showing branch-length values, constructed by the neighbor-joining method of Jukes and Cantor (1969). 


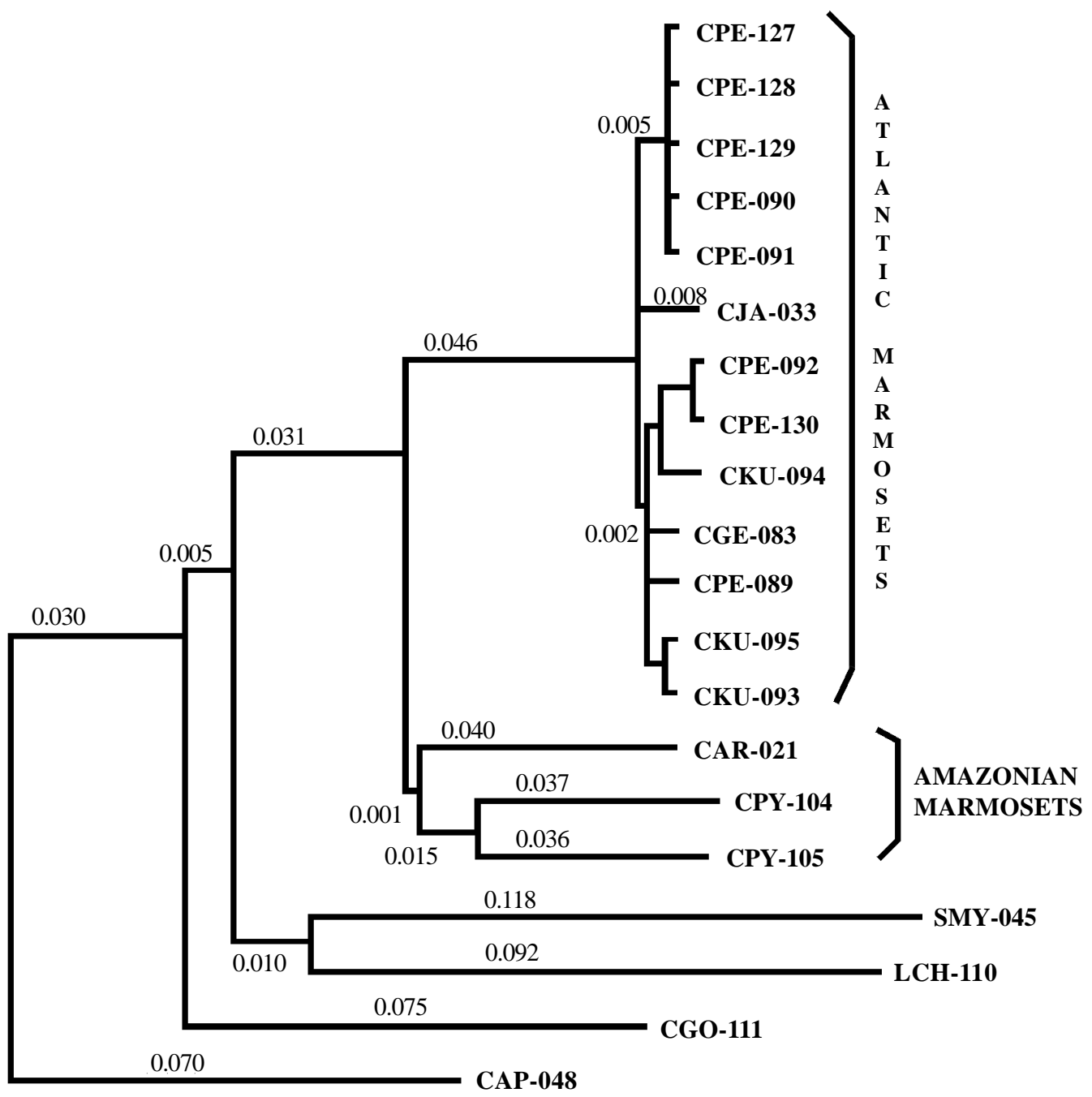

Figure 2 - ND1 gene-sequence phylogenetic dendrogram showing branch-length values, constructed by the neighborjoining method of Tamura and Nei (1993).

Table III - Nucleotide divergence matrix for the transferrin fragment (x100) obtained by the method of Jukes and Cantor (1969).

\begin{tabular}{|c|c|c|c|c|c|c|}
\hline Species & $\begin{array}{l}\text { Cebus } \\
\text { apella }\end{array}$ & $\begin{array}{l}\text { Callimico } \\
\text { goeldii }\end{array}$ & $\begin{array}{l}\text { Saguinus } \\
\text { mystax }\end{array}$ & $\begin{array}{l}\text { Leontopithecus } \\
\text { chrysomelas }\end{array}$ & $\begin{array}{c}\text { Callithrix } \\
\text { pygmaea } 105\end{array}$ & $\begin{array}{l}\text { Callithrix } \\
\text { jacchus }\end{array}$ \\
\hline Callimico goeldii & 5.56 & & & & & \\
\hline Saguinus mystax & 6.33 & 4.30 & & & & \\
\hline $\begin{array}{l}\text { Leontopithecus } \\
\text { chrysomelas }\end{array}$ & 5.31 & 3.72 & 4.38 & & & \\
\hline Callithrix pygmaea 105 & 5.47 & 3.30 & 4.21 & 3.63 & & \\
\hline Callithrix jacchus & 5.14 & 3.14 & 4.05 & 3.47 & 1.11 & \\
\hline Callithrix pygmaea 104 & 5.56 & 3.38 & 4.30 & 3.55 & 0.55 & 1.03 \\
\hline
\end{tabular}

pygmaea individuals. This value is comparable to values obtained between species of marmosets of different groups.

Based on the NJ dendrograms obtained for transferrin and ND1 sequences (Figures 1 and 2) and considering an estimate of 13 Mya (Goodman et al., 1998) as the time of the split of the Callitrichini from the other Platyrrhini, the timing of the separation of the lineages of the two $C$. pygmaea individuals was estimated as 1.8 Mya for transferrin and 5.4 Mya for ND1. The estimate of the time of separation between the two C. pygmaea individuals obtained by NJ dendrogram analysis (see Figure 3 ) of D-loop sequences was 4.0 Mya. 


\section{DISCUSSION}

Molecular data from the ND1 region indicate that $C$. pygmaea is more closely related to other Amazonian marmosets (argentata group, represented in this study by $C$. argentata) than to those of the Atlantic forest or the cerrado and caatinga (jacchus group; represented by C. jacchus, $C$. penicillata, C. kuhli, C. geoffroyi). This agrees with the results obtained by Canavez et al. (1996) based on karyology, and Tagliaro et al. (1997), Porter et al. (1997) and Almeida (1995), based on DNA sequences. The studies of Barroso et al. (1997) and Sena (1998), also based on DNA analysis, are inconclusive in defining whether C. pygmaea is more closely related to the argentata group or to the jacchus group. Based on detailed studies of morphological features and feeding habits, Rosenberger $(1981,1984)$ considered that the pygmy marmoset should be classified within the genus Callithrix, although this researcher believed that the pygmy marmoset was closely related to the jacchus group, a theory which contrasts with the molecular evidence.

The two C. pygmaea individuals were more different than would be expected for a monospecific group in which no subspecies have yet been described. There was a divergence of $7.4 \%$ in the ND1 divergence matrix which corresponds to values observed between marmosets of different groups. In the D-loop divergence matrix (Table V) the divergence between the two $C$. pygmaea individuals was $11.2 \%$. Similar values have been found only between $C$. aurita and other species of the jacchus group (C. aurita representing the most basal species of this group). All other intra-group divergence values were inferior to $8.0 \%$.

The calculated timing of separation of the two lineages of $C$. pygmaea ranges from 1.8 Mya (transferrin) to 5.4 Mya (ND1). In relative terms these dates are informative, being earlier than those for the emergence of the present species of the amended jacchus group in the same studies. Hershkovitz (1977) considered the possibility of the existence of subspecies of $C$. pygmaea, but did not agree with the subspecies C. p. niveiventris Lonneberg 1940, and Van Roosmalen and Van Roosmalen (1997) reopened this debate after observing the niveiventris morphotype in areas where it had not been thought to occur. Meireles et al. (1998), investigating protein variability, found that $C$. pygmaea $(\mathrm{N}=8)$ was the most variable species in a study involving 13 species and subspecies of callitrichines.

Apparently Callithrix pygmaea consists of two different subspecies or perhaps even two species. However, the individuals used in this study, like those in the study by Meireles et al. (1998), were captive animals from the "Centro Nacional de Primatas". These animals and their ancestors were of unknown geographical origin. In order to obtain more conclusive evidence, further molecular studies should be undertaken with more individuals of known geographical origin.

The 21 st century is going to be a critical period for the conservation of biodiversity, particularly in richly biodiverse areas such as the neotropical forests. Descriptions of new

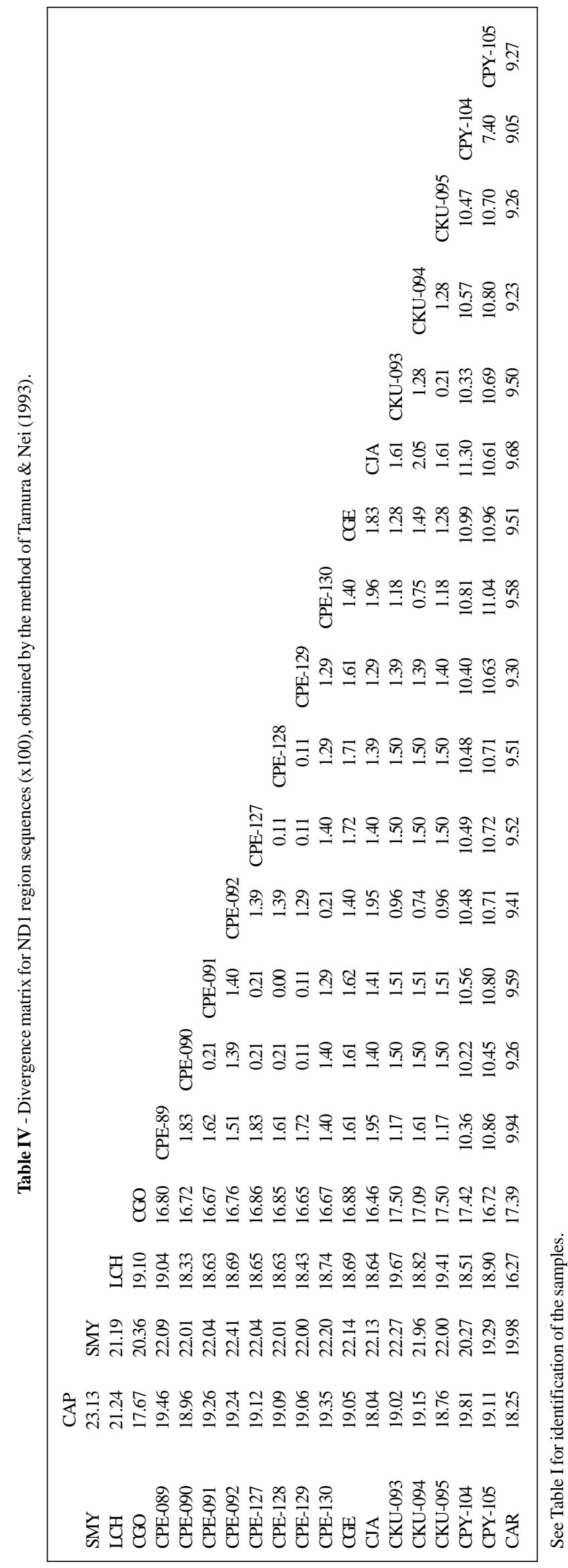




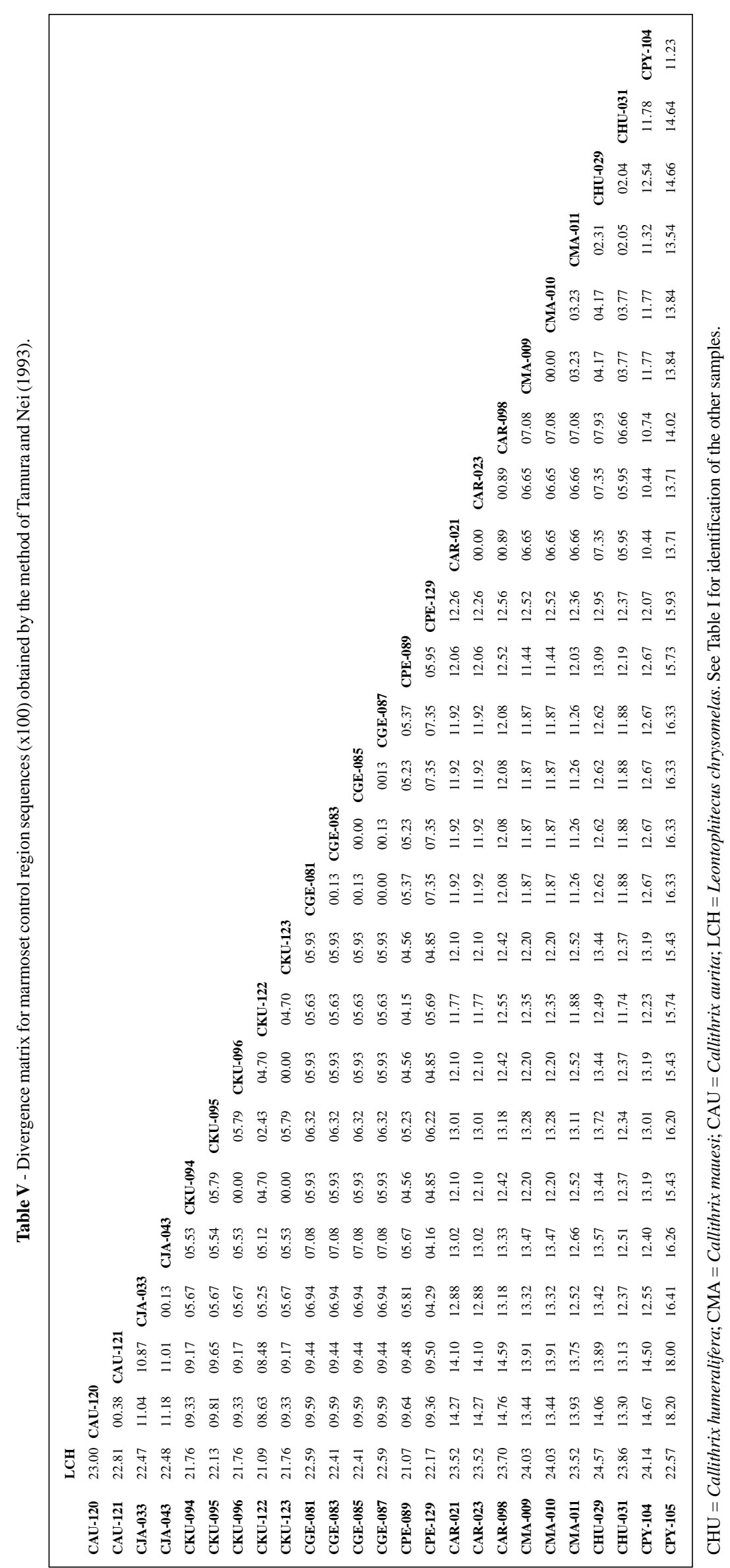




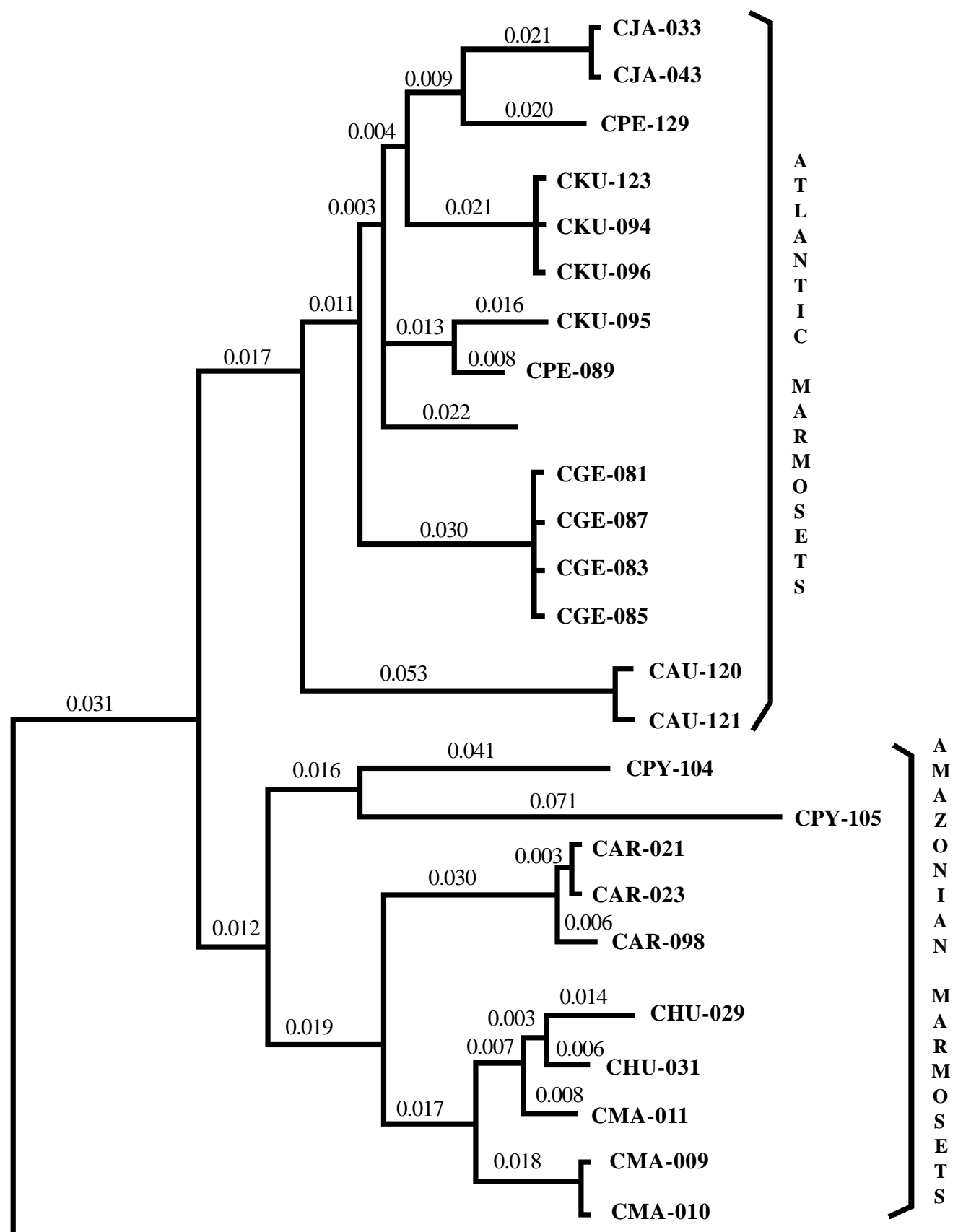

0.130

Figure 3 - D-loop phylogenetic dendrogram showing branch-length values, constructed by the neighbor-joining method of Tamura and Nei (1993). See Table I for identification of the samples. $\mathrm{CHU}=$ Callithrix humeralifera $; \mathrm{CMA}=$ Callithrix mauesi $\mathrm{CAU}=$ Callithrix aurita $; \mathrm{LCH}=$ Leontophitecus chrysomelas.

species and subspecies of plants and animals, some of which are restricted to small geographical areas or are from peculiar habitats, continue to be published, and species already described are having their taxonomic status revised, while habitat destruction is occurring at such a rate that many species become extinct before even being described.
Molecular genetics is a new approach to taxonomic classification. It is helping to evaluate biodiversity and aid decision-making concerning to the conservation priorities of many different taxa. The recognition of groups that exhibit very little evolutionary differentiation and those that are phylogenetically distinct allows direction of conserva- 
tion efforts to protect the maximum biological diversity so that priority can be given to those taxa most at risk of extinction. The possibility of the existence of different species and/or subspecies of Callithrix pygmaea surely necessitates a re-evaluation of their conservation status, particularly in the light of the trade in these small monkeys in certain areas such as the Iquitos region of Peru (Rylands et al., 1993).

\section{ACKNOWLEDGMENTS}

We would like to thank Dr. José Augusto Pereira Carneiro Muniz (Centro Nacional de Primatas, Belém, PA, Brazil), Dr. Adelmar Coimbra-Filho and Dr. Alcides Pissinati (Centro de Primatologia do Rio de Janeiro, RJ, Brazil), Arlindo Pinto de Souza Jr., Milton Thiago de Melo, and Criadouro Barbuse Leal for the samples used in this research. We thank Dr. Colin Robert Beasley for checking the English. C.H.T. was supported by the Brazilian research agency CNPq. This research was made possible by grants to M.J.S. from the Nuffield Foundation, the Royal Society, and Northern Ireland Development and Research.

\section{RESUMO}

As classificações tradicionais envolvendo os macacos da infraordem Platyrrhini, principalmente baseadas em características morfológicas, têm sido contestadas por dados moleculares recentes. A subfamília Callitrichinae (Platyrrhine, Primates) engloba um diverso grupo de espécies, muitas das quais consideradas em perigo de extinção. A presente análise de duas regiões do DNA, um gene mitocondrial (ND1) e um gene nuclear (regiões intrônicas da transferrina), sugerem que Callithrix pygmaea apresenta variabilidade suficiente para justificar a existência de subespécies ou até mesmo de espécies distintas. As árvores filogenéticas baseadas na região do ND1 indicam que esta espécie está relacionada mais proximamente aos marmosets amazônicos do que aos da mata Atlântica. Estes resultados reabrem a discussão sobre diversidade e programas de conservação baseados apenas em classificações taxonômicas tradicionais.

\section{REFERENCES}

Almeida, R.A.C. (1995). Estudo das relações intergenéricas na subfamília Callitrichinae usando o intron 11 do gene do fator de von Willebrand. Master's thesis, Universidade Federal do Pará, Museu Paraense Emílio Goeldi \& Empresa Brasileira de Pesquisas Agropecuárias, Belém, PA

Barroso, C.M.L., Schneider, H., Schneider, M.P.C., Sampaio, I., Harada, M.L., Czelusniak, J. and Goodman, M. (1997). Update on phylogenetic systematics of New World monkeys: further DNA evidence for placing the pygmy marmoset (Cebuella) within the marmoset genus Callithrix. Int. J. Primatol. 18: 645-668.

Cabot, E.L. and Beckenbach, A.T. (1989). Simultaneous editing of multiple nucleic acid and protein with ESEE. Comput. Appl. Biosci. 5: 233-234.

Cabrera, A. (1958). Catálogo de los mamíferos de America del Sur. Rev. Mus. Argent. Cienc. Nat. "Bernadino Rivadavia" 4: 1-307.

Canavez, F., Alves, G., Fanning, T.G. and Seuánez, H.N. (1996). Comparative karyology and evolution of the Amazonian Callithrix (Platyrrhini, Primates). Chromosoma 104: 348-357.

Dollman, G. (1933). Primates, Series 3. British Museum (Natural History), London.

Felsenstein, J. (1985). Confidence limits on phylogenies: an approach using the bootstrap. Evolution 39: 783-791.
Ford, S.M. (1986). Systematics of the New World monkeys. In: Comparative Primate Biology (Swindler, D.R. and Erwin, J., eds.). Alan R. Liss Inc., New York, pp. 73-135.

Goodman, M., Porter, C.A., Czelusniak, J., Page, S.L., Schneider, H., Shoshani, J., Gunnel, G. and Groves, C.P. (1998). Toward a phylogenetic classification of primates based on DNA evidence complemented by fossil evidence. Mol. Phylogenet. Evol. 9: 585-598.

Hendy, M.D. and Penny, D. (1982). Branch and Bound algorithms to determine minimal evolutionary trees. Math. Biosci. 59: 277-290.

Hershkovitz, P. (1977). Living New World Monkeys (Platyrrhini); With an Introduction to Primates. The University of Chicago Press, Chicago.

Hillis, D.M. and Bull, J.J. (1993). An empirical test of bootstrapping as a method for assessing confidence in phylogenetic analysis. Syst. Biol. 42: 182-192.

Jukes, T.H. and Cantor, C.R. (1969). Evolution of protein molecules. In: Mammalian Protein Metabolism (Munro, H.N., ed.). Academic Press, New York, pp. 21-132.

Kay, R.F. (1994). Giant tamarin from the Miocene of Colombia. Am. J. Phys. Anthropol. 95: 333-353.

Kimura, M. (1980). A simple method for estimating evolutionary rate of base substitution through comparative studies of nucleotide sequences. $J$. Mol. Evol. 16: 111-120.

Kumar, S., Tamura, K. and Nei, M. (1993). MEGA: Molecular Evolutionary Genetics Analysis. The Pennsylvania State University, University Park.

Meireles, C.M., Czelusniak, J., Sampaio, I., Schneider, H., Ferrari, S.F., Coimbra-Filho, A.F., Pissinatti, A., Muniz, J.A., Ferreira, H.S. and Schneider, M.P. (1998). Electrophoretic polymorphisms and their taxonomic implications in Callitrichini. Biochem. Genet. 36: 229-244.

Napier, J.S. and Napier, P.H. (1967). A Handbook of Living Primates. Academic Press, New York.

Pastorini, J., Forstner, M.R.J., Martin, R.D. and Melnick, D.J. (1998). A reexamination of the phylogenetic position of Callimico (Primates) incorporating new mitochondrial DNA sequence data. J. Mol. Evol. 47: $32-41$.

Porter, C.A., Czelusniak, J., Schneider, H., Schneider, M.P.C., Sampaio, I. and Goodman, M. (1997). Sequences of the primate $\varepsilon$-globin gene: implications for systematics of the marmosets and other New World primates. Gene 205: 59-71.

Rosenberger, A.L. (1981). Systematics: the higher taxa. In: Ecology and Behavior of Neotropical Primates (Coimbra-Filho, A.F. and Mittermeier, R.A., eds.). Academia Brasileira de Ciências, Rio de Janeiro, pp. 9-27.

Rosenberger, A.L. (1984). Aspects of the systematics and evolution of the marmosets. In: A Primatologia no Brasil (Mello, M.T.D., ed.). Sociedade Brasileira de Primatologia, Brasília, pp. 159-180.

Rylands, A.B., Coimbra-Filho, A.F. and Mittermeier, R.A. (1993). Systematics, geographic distribution, and some notes on the conservation status of the Callitrichidae. In: Marmosets and Tamarins. Systematics, Behaviour and Ecology (Rylands, A.B., ed.). Oxford University Press, Oxford, pp. 11-77.

Rylands, A.B., Mittermeier, R.A. and Rodriguez-Luna, E. (1995). A species list for the New World primates (Platyrrhini): distribution by country, endemism, and conservation status according to the Mace-Land system. Neotropical Primates 3 (Suppl.): 113-160.

Rylands, A.B., Mittermeier, R.A. and Rodriguez-Luna, E. (1997). Conservation of neotropical primates: threatened species and an analysis of primate diversity by country and region. Folia Primatol. 68: 134-160.

Sambrook, J., Fritsch, E.F. and Maniatis, T. (1989). Molecular Cloning: A Laboratory Manual. 2nd edn. Cold Spring Harbor Laboratory Press, Cold Spring Harbor, New York.

Sarich, V.M. and Wilson, A.C. (1973). Generation time and genomic evolution in primates. Science 179: 1144-1147.

Schneider, H., Sampaio, I., Harada, M.L., Barroso, C.M.L., Schneider, M.P.C., Czelusniak, J. and Goodman, M. (1996). Molecular phylogeny of the New World monkeys (Platyrrhini, Primates) based on two nuclear genes: IRBP intron 1 and $\varepsilon$-globin sequences. Am. J. Phys. Anthropol. 100: 153-179.

Sena, L. (1998). Filogenia do gênero Callithrix Erxleben 1777 (Callitrichinae, Platyrrhini) baseada em seqüências do gene mitocondrial da citicromo oxidase II (CoII). Master's thesis, Curso de Pós-graduação em Ciências Biológicas da Universidade Federal do Pará, Belém.

Simons, E.L. (1972). Primate Evolution: An Introduction to Man's Place in 
Nature. Macmill, New York.

Simpson, G.G. (1945). The principles of classification of mammals. Bull. Am. Mus. Nat. Hist. 85: 1-350.

Stirton, R.A. (1951). Ceboid monkeys from the Miocene of Colombia. Univ Calif. Publ., Bull. Depart. Geol. Sci. 28: 315-356.

Swofford, D.L. (1998). PAUP*. Phylogenetics Analysis Using Parsimony (*and other methods). Version 4. Sinauer Associates, Sunderland, Massachusetts.

Tagliaro, C.H., Schneider, M.P.C., Schneider, H., Sampaio, I.C. and Stanhope, M. (1997). Marmoset phylogenetics, conservation perspectives, and evolution of the mtDNA control region. Mol. Biol. Evol. 14:
674-684.

Tamura, K. and Nei, M. (1993). Estimation of the number of nucleotide substitutions in the control region of the mitochondrial DNA in humans and chimpanzees. Mol. Biol. Evol. 10: 512-526.

Thomas, O. (1913). On some rare Amazonian mammals from the collection of the Pará Museum. Ann. Mag. Nat. Hist. (Series 8) 11: 130-136.

Van Roosmalen, M.G.M. and Van Roosmalen, T. (1997). An eastern extension of the geographical range of the pygmy marmoset, Cebuella pygmaea. Neotropical Primates, 5: 3-6.

(Received May 26, 2000) 
